Creative Commons User License: CC BY-NC-ND

Abstracted by: EBSCOhost, Electronic Journals Service (EJS),

Google Scholar, Journal Seek, Scientific Commons,

Food and Agricultural Organization (FAO), CABI and Scopus

http://eoi.citefactor.org/10.11226/v23i2
Journal of Agricultural Extension

Vol. 23 (2) April, 2019

ISSN(e): 24086851; ISSN(Print); 1119944X

http://journal.aesonnigeria.org

http://www.ajol.info/index.php/iae

Email: editorinchief@aesonnigeria.org

\title{
Characteristics of Catfish Marketing in Egor Local Government Area of Edo State, Nigeria \\ https://dx.doi.org/10.4314/jae.v23i2.17
}

\section{Omoregbee Friday. E}

Agricultural Economics and Extension Services,

University of Benin Edo State, Nigeria

Email: Egbenayabuwaomoregbee@yahoo.com, Phone:08027448973

\section{Abiola Matthew.O.}

Agricultural Economics and Extension,

Federal University Oye, Ekiti State Nigeria

Email: maidenjournal@yahoo.com, Phone:08027833681

\section{Okogba Godbless.A.}

Agricultural Economics and Extension Services,

University of Benin, Edo State Nigeria

Email: okogba godbless@uniben.edu.ng, Phone:09023380492

\section{Abstract}

The study examined the characteristics of catfish marketing in Egor Local Government Area of Edo State, Nigeria. Multistage sampling technique was used to select four communities: Isihor, Evbomore, Ekheoba and Odigi. This was followed by random sampling of one central market in each community and fifteen respondents were sampled randomly from each central market in each community giving a total sample size of sixty respondents. Data were analysed using mean, percentages gamma, chi square and Pearson product moment correlation. Results showed that 95\% sourced their marketing information very often from catfish marketers/farmers and $70 \%$ sourced information from other marketers such as poultry or vegetable marketers. Only $11.42 \%$ had access to information on improved technology through extension agents while 56.3\% derived their information from family members. Technologies adopted were clean-washing (96.7\%), grading by size (95\%) by weight (71.7\%), by quality (81.7\%), by source (85\%), solar drying (88.3\%), sorting (90\%), hot smoking (93.3\%) cold smoking (80\%), and half drum smoking (91.7\%). A positive significant relationship between respondents' use of information channels and their intensity of performing catfish marketing functions was observed. The study established that extension service delivery was poor and newspaper, radio, magazine, bulleting, internets and cooperative society were not good source of information for improved catfish technologies in the study areas. Extension agent frequency of contacts with catfish farmers/marketers should be increased to improve extension service delivery and concentrate effort on those catfish technologies with low adoption

Key words: Extension service delivery, adoption of Improved catfish practices 


\section{Introduction}

Catfish like other food from animal sources, provides high quality protein that contains all the necessary amino acid to build and replace protein in the body. Thus, catfish production and marketing are an appropriate system to feed the fast-growing population and also plays an important role in household food security. Due to these features, it is important and necessary to increase the production to make it easily accessible, available and affordable to all. The goal of extension is to ensure that increased agricultural productivity is achieved by stimulating farmers to use modern and scientific production technologies developed through research. There are problems associated with catfish production in Nigeria which improve technologies can solve, these problems include: pond construction, liming pond water treatment, pond water treatment, pond fertilization, pond maintenance, stocking density, and drug administration (Anugwa Agwu and Anyanwu 2017). Research had shown that marketers' information exposure is most likely to be an important factor influencing their adoption behavior as greater exposure is likely to enhance awareness about the latest recommendations and to lead marketers putting these recommendations into practice in a precise manner. Most catfish marketers lack the technical knowhow. Farmers depend on information or knowledge gotten from extension agent, but how regular and timely are these services provider in meeting the needs of catfish marketers. Therefore, the study examined extension service delivery and adoption of improved practices among catfish marketers

\section{Purpose of the study}

The overall purpose of the study was to examined extension service delivery and adoption of improve practices among catfish marketers. The specific objectives include to: estimate the level of contact between extension agent and catfish marketers:

- examine the socioeconomic characteristics of persons involved in catfish marketing;

- identify the sources of information on marketing of catfish;

- identify channels for advertising catfish market;

- determine the rate of adoption of improve practices;

- examine the relationship between socio-economic characteristics and adoption of improved catfish marketing technologies; and

- examine the relationship between information channels and intensity of performing catfish marketing functions;

\section{Methodology}

The study was conducted in Egor Local Government Areas of Edo State, Nigeria. Multistage sampling technique was used to select four communities: Isihor, Evbomore, Ekheoba and Odigi. This was followed by random sampling of one central market in each community. Finally, fifteen respondents were sampled randomly from each central market giving a total sample size of sixty respondents for the study. Data were analysed using mean, percentages, gamma, chi square and Pearson product moment correlation.

\section{Hypothesis}

$\mathbf{H}_{01}$ : There is no significant relationship between respondents use of information channels and their intensity of performing catfish marketing functions

$\mathrm{H}_{02}$ : There is no significant relationship between respondents' socio-economic characteristics and their adoption intensity of improved catfish marketing technologies. 
Creative Commons User License: CC BY-NC-ND

Abstracted by: EBSCOhost, Electronic Journals Service (EJS), Google Scholar, Journal Seek, Scientific Commons,

Food and Agricultural Organization (FAO), CABI and Scopus
Journal of Agricultural Extension

Vol. 23 (2) April, 2019

ISSN(e): 24086851; ISSN(Print); 1119944X

http://journal.aesonnigeria.org

http://www.ajol.info/index.php/iae

Email: editorinchief@aesonnigeria.org

\section{Results and Discussion}

\section{Socioeconomic Characteristics of Respondents}

Table 1 shows that a greater percentage (90.0\%) of the respondents were female. The majority (56.7\%) were between the age of $24-34$ years of age with a mean of 38 years. Similarly, greater percentage $(85.0 \%)$ of the respondents were married. The marketers had average family size of four. The majority $(60.0 \%)$ of the fish marketers had secondary school certificate, $28.3 \%$ had tertiary education certificate $10.0 \%$ had primary school certificate, while $1.7 \%$ had no formal education. This finding is contrary to the findings of Umoinyang (2014) that most $(76 \%)$ of the marketers did not have degree certificate. The average level of experience of the fish marketers was six years. The majority $(48.3 \%)$ had 1 - 5 years marketing experience, while $41.7 \%$ of the fish marketers had $6-10$ years of experience. This finding is similar to the findings of Umoinyang (2014) that greater percentage $(59.53 \%)$ of fish marketers have $1-11$ years of marketing experience. Also, $(93.3 \%)$ of the respondents used family labour, while $6.7 \%$ used hired labour in their fish marketing activities. The majority (55.0\%) of the fish marketers indicated that they do not belong to any association. A greater percentage of the marketers (95.0\%) operate the business on full-time basis. Akembor and lke (2015) reported that greater proportion $(88.8 \%)$ of fish marketers operate fish marketing on full time bases. 
Creative Commons User License: CC BY-NC-ND

Journal of Agricultural Extension

Abstracted by: EBSCOhost, Electronic Journals Service (EJS), Vol. 23 (2) April, 2019

Google Scholar, Journal Seek, Scientific Commons,

ISSN(e): 24086851; ISSN(Print); $1119944 X$

Food and Agricultural Organization (FAO), CABI and Scopus

http://journal.aesonnigeria.org

http://www.ajol.info/index.php/jae

http://eoi.citefactor.org/10.11226/v23i2

Email: editorinchief@aesonnigeria.org

Table 1: Socio-economic characteristics of respondents

\begin{tabular}{|c|c|c|c|}
\hline Variables & Class & Percentages (\%) & Mean \\
\hline \multirow[t]{5}{*}{ Age (in years) } & $24-31$ & 20.0 & \\
\hline & $32-39$ & 36.7 & \\
\hline & $40-47$ & 31.7 & \\
\hline & $48-55$ & 6.7 & 38 \\
\hline & $56-60$ & 5.0 & \\
\hline \multirow[t]{3}{*}{ Sex } & Male & 10.0 & \\
\hline & Female & 90.0 & \\
\hline & Single & 13.3 & \\
\hline \multirow[t]{4}{*}{ Marital status } & Married & 85.0 & \\
\hline & Divorced & 0.0 & \\
\hline & Widowed & 1.7 & \\
\hline & $1-2$ & 8.3 & \\
\hline \multirow[t]{3}{*}{ Household size } & $3-4$ & 41.7 & \\
\hline & $5-6$ & 40.0 & 4 persons \\
\hline & $7-8$ & 10.0 & \\
\hline \multirow[t]{4}{*}{ Educational background } & None & 1.7 & \\
\hline & Primary & 10.0 & \\
\hline & Secondary & 60.0 & \\
\hline & Tertiary & 28.3 & 1.9 years \\
\hline \multirow[t]{5}{*}{ Marketing experience } & $1-5$ & 48.3 & \\
\hline & $6-10$ & 41.7 & \\
\hline & $11-15$ & 6.7 & \\
\hline & $16-20$ & 1.7 & 6 \\
\hline & $21-25$ & 1.7 & \\
\hline Source of labour & $\begin{array}{l}\text { Family } \\
\text { Hired }\end{array}$ & $\begin{array}{l}93.3 \\
6.7\end{array}$ & \\
\hline Membership of cooperative society & $\begin{array}{l}\text { Yes } \\
\text { No }\end{array}$ & $\begin{array}{l}45.0 \\
55.0\end{array}$ & \\
\hline Type of marketing enterprise & $\begin{array}{l}\text { Full time } \\
\text { Part time }\end{array}$ & $\begin{array}{l}95.0 \\
5.0\end{array}$ & \\
\hline Marketing scale in kg & $\begin{array}{l}\text { 10-60 small scale } \\
61-121 \text { Medium } \\
\text { 122-150 Large Scale }\end{array}$ & $\begin{array}{l}90.0 \\
6.7 \\
3.3\end{array}$ & 37 \\
\hline
\end{tabular}

\section{Source: Field Data 2018}

\section{Sources of Information on Improved Catfish Marketing Practices}

Table 2 shows that $95.0 \%$ of the respondents sourced their information very often from catfish marketers and farmers $(70.0 \%)$. other farmers such as vegetable, poultry and tree crop farmers, extension agents (88.3\%) family members (43.3\%) newspaper (93.3\%). The finding is at variance with that of Kughur Tumba and Ogunlase (2017) that the main source of information's on agricultural enterprise in Nigeria is researcher; journals, conference proceedings, books, National Bureau of Statistics (NBS), and periodicals. 
Creative Commons User License: CC BY-NC-ND

Abstracted by: EBSCOhost, Electronic Journals Service (EJS), Google Scholar, Journal Seek, Scientific Commons,

Food and Agricultural Organization (FAO), CABI and Scopus
Journal of Agricultural Extension

Vol. 23 (2) April, 2019

ISSN(e): 24086851; ISSN(Print); 1119944X

http://journal.aesonnigeria.org

http://www.ajol.info/index.php/jae

Email: editorinchief@aesonnigeria.org

http://eoi.citefactor.org/10.11226/v23i2

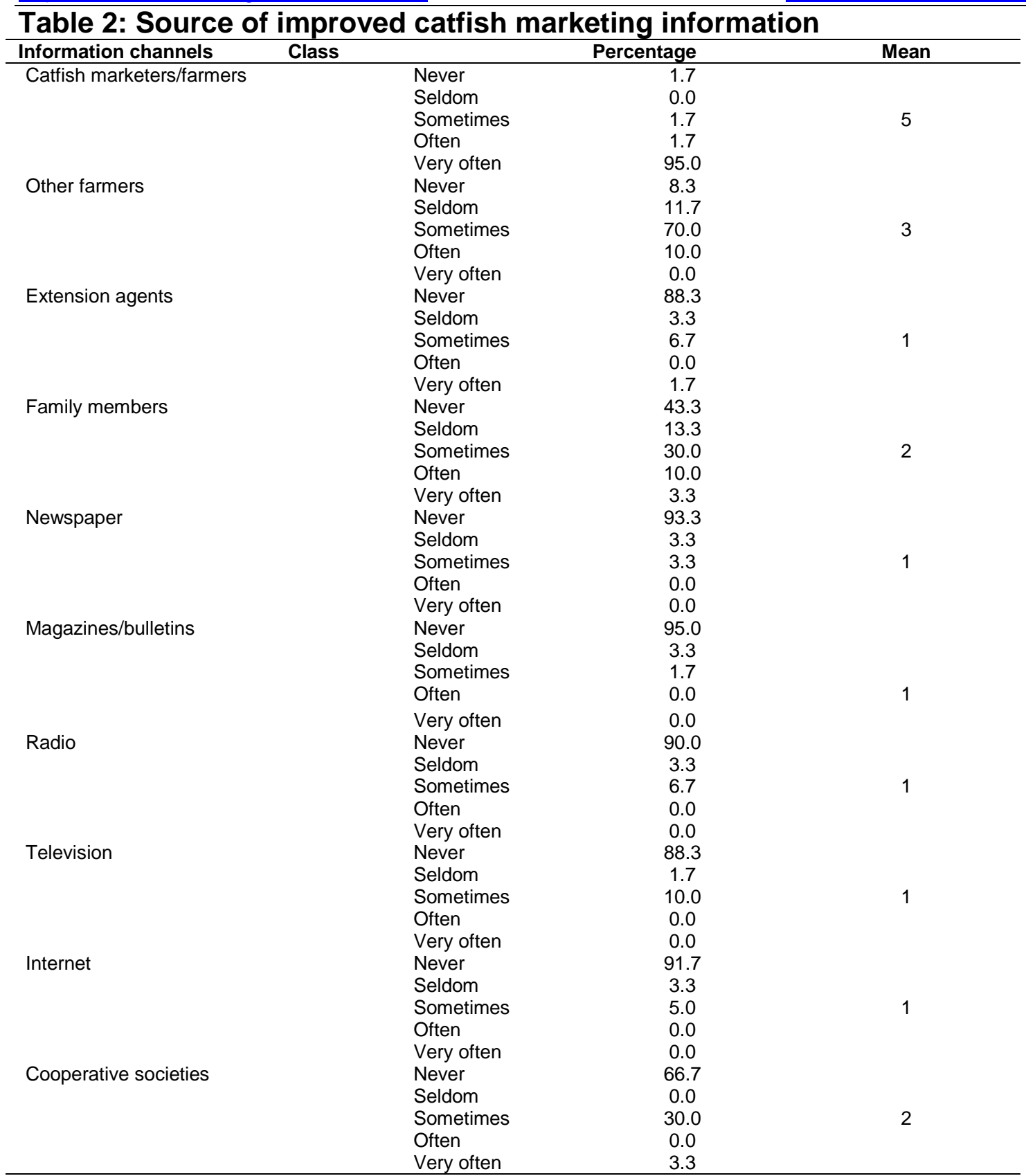

Source: Survey data, 2018

\section{Channels of Advertising Catfish Market}

Table 3 shows that a greater percentage $(66.7 \%)$ of the respondents had sign posts, to promote sales, $48.30 \%$ promote their catfish marketing enterprise using fliers ,33.90\% display sales by advertising in the media. This implies that farmers are involved in marketing catfish through advertising via radio, television and internets making their fish visible to large number of potential buyers at close and long-distance places which is in agreement with the findings of Foluso and Taiwo (2018) that cost of marketing has a great influence on sales through promotion, advertising. 
Creative Commons User License: CC BY-NC-ND

Abstracted by: EBSCOhost, Electronic Journals Service (EJS), Google Scholar, Journal Seek, Scientific Commons,

Food and Agricultural Organization (FAO), CABI and Scopus

http://eoi.citefactor.org/10.11226/v23i2
Journal of Agricultural Extension

Vol. 23 (2) April, 2019

ISSN(e): 24086851; ISSN(Print); 1119944X

http://journal.aesonnigeria.org

http://www.ajol.info/index.php/iae

Email: editorinchief@aesonnigeria.org

Table 3: Channels for marketing catfish

\begin{tabular}{ll}
\hline Channels & $\begin{array}{l}\text { Percentage } \\
\text { (Yes) }\end{array}$ \\
\hline Advertising and promotion & 33.90 \\
Labelling & 1.70 \\
Marketing news and statistics & 1.70 \\
Fliers & 48.30 \\
Sign post & 66.70
\end{tabular}

Source: Field survey, 2018

\section{Use Economic Opportunities in Catfish Marketing}

Table 4 shows that $8.30 \%$ of the respondents insured their catfish marketing business, $38.3 \%$ had access to grants, $5.0 \%$ had access to leasehold, while $11.7 \%$ had no access to hedging in the study area. This implies that in the event of death of the fishes and other loss, the catfish marketers would be at a great loss due to non-insurance of their fish business which is in agreement with the finding of Abiola (2017), that the importance of insurance among farming household and the likelihood of loss because of the biological nature of farm business

Table 4: Use of economic opportunities catfish marketing

\begin{tabular}{ll} 
Value addition through ownership & Percentage (Yes) \\
\hline Insurance & 8.30
\end{tabular}

Credit

86.70

Grants

38.30

Leasing

5.00

Hedging 11.7

Source: Field survey, 2018 
Creative Commons User License: CC BY-NC-ND

Abstracted by: EBSCOhost, Electronic Journals Service (EJS),

Google Scholar, Journal Seek, Scientific Commons,

Food and Agricultural Organization (FAO), CABI and Scopus
Journal of Agricultural Extension

Vol. 23 (2) April, 2019

ISSN(e): 24086851; ISSN(Print); 1119944X

http://journal.aesonnigeria.org

http://www.ajol.info/index.php/jae

Email: editorinchief@aesonnigeria.org

http://eoi.citefactor.org/10.11226/v23i2

\section{Adoption of Improved Methods of Processing Catfish for Marketing}

Table 5 shows that the respondents adopted the following improved catfish marketing practices: clean-washing (96.7\%), grading by size (95\%) by weight $(71.7 \%)$, by quality $(81.1 \%)$ by source $(85 \%)$, sorting $(90 \%)$, solar drying $(88.3 \%)$, hot smoking $(93.3 \%)$, cold smoking (80\%). use of half drum smoking kiln (91.7\%) and cold smoking preservation $(80 \%)$. The result is in agreement with that of Adisa, Ahmed. Ebenehi and Oyibo (2019), which indicates a high level of adoption of improve practices in rice production. The implication is that farmers are rational and will be willing to adopt technology that improves their enterprise (Abiola ,2017)

Table 5: Adoption of improved methods of processing catfish for marketing

\section{Standard catfish marketing practices Percentage} Adoption

Cleaning washing 96.7

Gutting

Grading by size (Table size)

Grading by weight (50kg per basket)

Grading by quality

Grading by source (River of pond)

Basin grading

Sorting table

Mechanical grader

Solar drying

Agro-waste drying

Hot smoking

Cold smoking

Brine salting

Use of Ice blocks

Use of cold air

Half drum smoking kiln

Chorker smoking kiln

Altona smoking kiln

Watanabe smoking kiln

0.0

Kanji smoking kiln

0.0

Electric smoking kiln 1.7

Source: Field Data 2018 
Creative Commons User License: CC BY-NC-ND

Abstracted by: EBSCOhost, Electronic Journals Service (EJS),

Google Scholar, Journal Seek, Scientific Commons,

Food and Agricultural Organization (FAO), CABI and Scopus
Journal of Agricultural Extension

Vol. 23 (2) April, 2019

ISSN(e): 24086851; ISSN(Print); 1119944X

http://journal.aesonnigeria.org

http://www.ajol.info/index.php/jae

Email: editorinchief@aesonnigeria.org

\section{Relationship between Information Channels and Intensity of Performing Catfish Marketing Functions}

Table 6 shows that there was a positive significant relationship $(r=0.001, p \leq 0.01)$ between respondents' use of information channels and their intensity of performing catfish marketing functions. This implies that as more catfish marketers use the information channels, their intensity of performance in catfish marketing tends to increase in the positive direction. This finding is in line with the findings of Anugwa et al. (2017) which reported a positive relationship between information channels and intensity of performance of marketing functions. The indication that access to information had positive effect on catfish marketer performance.

Table 6: Use of information channels and intensity of performing catfish marketing functions

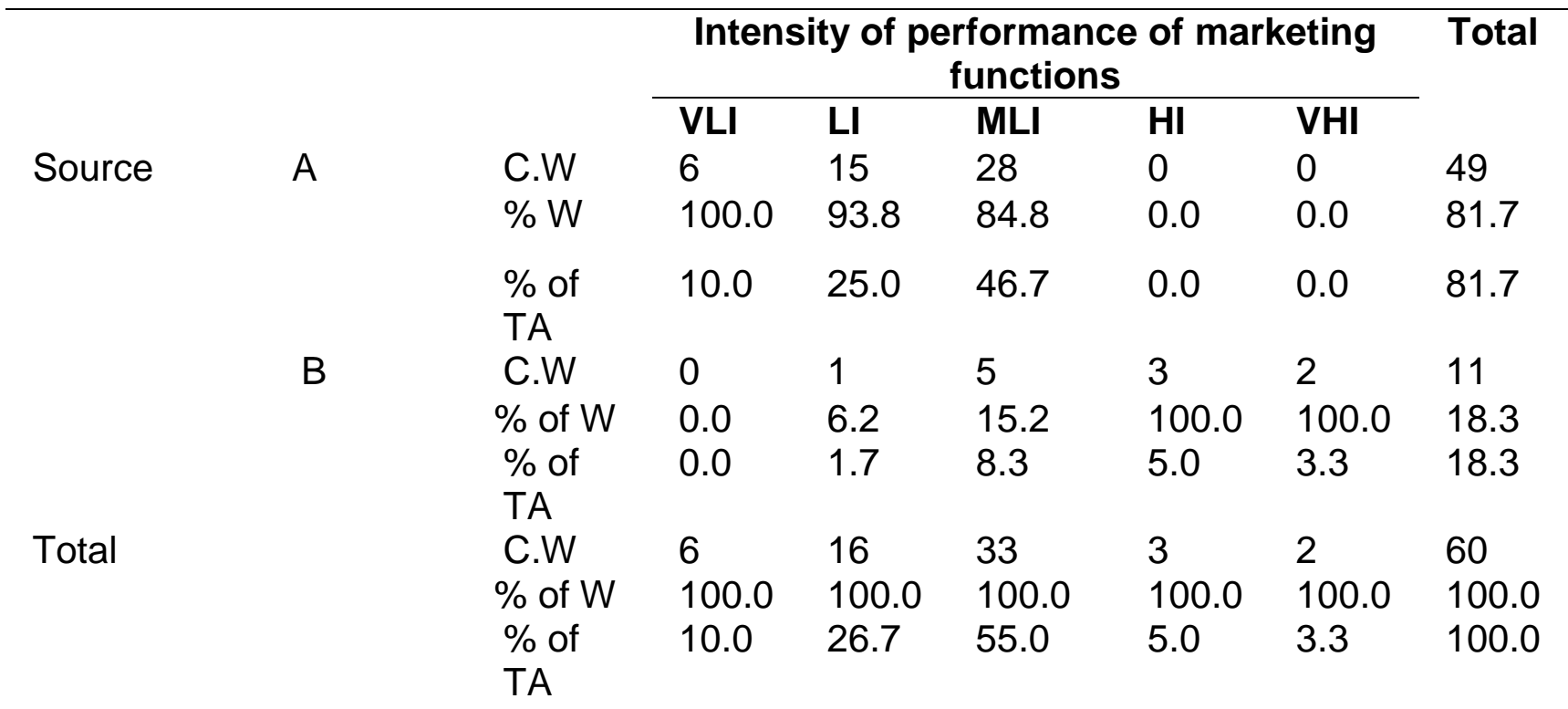

Key: $C W=$ count within, $T A=$ total: $A=S e l d o m=B=S o m e t i m e s$

$\mathrm{VLI}=$ very low intensity: $\mathrm{LI}=$ low intensity $=\mathrm{MLI}=$ moderately low intensity

$\mathrm{HI}=$ high intensity $=\mathrm{VHI}=$ very high intensity 
Creative Commons User License: CC BY-NC-ND

Abstracted by: EBSCOhost, Electronic Journals Service (EJS),

Google Scholar, Journal Seek, Scientific Commons,

Food and Agricultural Organization (FAO), CABI and Scopus
Journal of Agricultural Extension

Vol. 23 (2) April, 2019

ISSN(e): 24086851; ISSN(Print); 1119944X

http://journal.aesonnigeria.org

http://www.ajol.info/index.php/jae

Email: editorinchief@aesonnigeria.org

\section{Relationship between Socio-Economic Characteristics and Adoption of Improved Catfish Marketing Technologies}

Table 7 shows that there was a positive significant relationship $(r=0.043, p \leq 0.05)$ between marital status and adoption of improved catfish marketing technologies implying that as more catfish marketers married, their adoption tends to increase. The result also shows that there was a positive significant relationship ( $r=0.002, p \leq 0.05)$ between source of labour and adoption intensity of improved catfish marketing technologies. Respondents' contact with ADP and adoption intensity of improved catfish marketing technologies also shows a positive significant relationship $(r=0.000, p \leq 0.01)$. This implies that as more catfish marketers come in contact with ADP agents their adoption intensity tends to increase. Frequency of contact with ADP and adoption intensity of improved catfish marketing technologies had a positive significant relationship ( $r=0.000, p \leq 0.01$ ) implying the frequent contact with ADP agents increased the adoption intensity of the catfish marketers in the study area. There was a positive significant relationship ( $r=0.001, p \leq 0.01$ ) between marketing experience and adoption intensity of improved catfish marketing technologies. It implies that more years involved in marketing of catfish would increase adoption intensity of improved catfish marketing technologies. There was a positive significant relationship ( $r=0.002, p \leq 0.01$ ) between scale of marketing enterprise and adoption intensity of improved catfish marketing technologies implying an increase in scale of marketing increases adoption intensity of improved catfish marketing in the study area. The outcome is in agreement with Olomu and Adeyemi (2016) who worked on adoption and emarketing in paint industry

Table 7: Relationship between respondents' socio-economic characteristics and adoption of improved catfish marketing technologies

\begin{tabular}{lll}
\hline Variable & $\begin{array}{l}\text { Chi- } \\
\text { Square }\end{array}$ & df \\
\hline Marital Status & \\
Source of labour & $6.306^{*}$ & 2 \\
Contact with ADP & $9.192^{* * *}$ & 1 \\
Frequency of contact with ADP & $13.854^{\star * *}$ & 1 \\
Marketing experience & $19.091^{* * *}$ & 1 \\
Scale of marketing enterprise $^{\star * *}$ & $19.670^{\star}$ & 4 \\
\hline
\end{tabular}

$*=P<0.05$.

\section{Conclusion and Recommendations}

A good number sourced their marketing information from fellow catfish marketers/farmers Few received information from extension agents $A$ positive significant relationship exists between respondents' use of information channels and their intensity of performing catfish marketing functions was observed. Extension service delivery was poor and newspaper, radio, magazine, bulleting, internets and cooperative society were not good source of information for transferring improved technologies in the study areas. Extension agent frequency of contacts with catfish farmers/marketers should be increased to improve extension service delivery and concentrate effort on those catfish technologies with low adoption 
Creative Commons User License: CC BY-NC-ND

Abstracted by: EBSCOhost, Electronic Journals Service (EJS), Google Scholar, Journal Seek, Scientific Commons,

Food and Agricultural Organization (FAO), CABI and Scopus
Journal of Agricultural Extension

Vol. 23 (2) April, 2019

ISSN(e): 24086851; ISSN(Print); 1119944X

http://journal.aesonnigeria.org

http://www.ajol.info/index.php/jae

Email: editorinchief@aesonnigeria.org

\section{References}

Abiola M.O. (2017) Evaluation of Physical and financial value of food Losses during marketing of water melon under tropical climates. International Journal of Business and Management Studies,6(02):45-52

Adisa R.S.:Ahmed T.A. Ebenehi O.and Oyibo F.O.(2019) Perceived benefits of adoption of improved rice production technologies among small - scale farmers in Kogi state, Nigeria. Journal of Agricultural Extension 23(1):138-148

Anugwa, I. Q., Agwu, A.E. and Anyanwu, I.A. (2017). Catfish farmers' perception of training effectiveness of the University of Nigeria-West Africa Agricultural Productivity Programme. Journal of Agricultural Extension, 21 (2): 129-141.

Akembor A.S. and Ike P.C. (2015) Analysis of technical efficiency of catfish farming in Edo State, Nigeria. Journal of Biology Agriculture and Healthcare 5(2):93-99

Federal Bureau of Statistics (FBS), (2018). Annual abstract of statistics of Nigeria. Abuja, Nigeria.

Foluso O.and Taiwo A. (2018) Economic analysis of market performance of fresh fish in Lagos State, Nigeria. International Journal of Environment Agriculture and Biotechnology 2(3):594-560.

Kughur P.G.Tumba D. and Ogunlase O.O(.2017) Assessment of agricultural information sourcing and linkages between research and extension organizations in Benue State, Nigeria. Direct Research Journal of Agriculture and Food Science 5(4):1-7

Olomu M O. and Adeyemi I.I. (2016) E-Marketing adoption and performance in the Nigerian paints industry. International Journal of Economics, Commerce and Management 4(2):235-252

Umoinyang, M.E. (2014) Economics of fish marketing in Akwa lbom State, Nigeria. Masters Dissertation, Department of Agricultural Economics, University of Nsukka, Enugu State. 